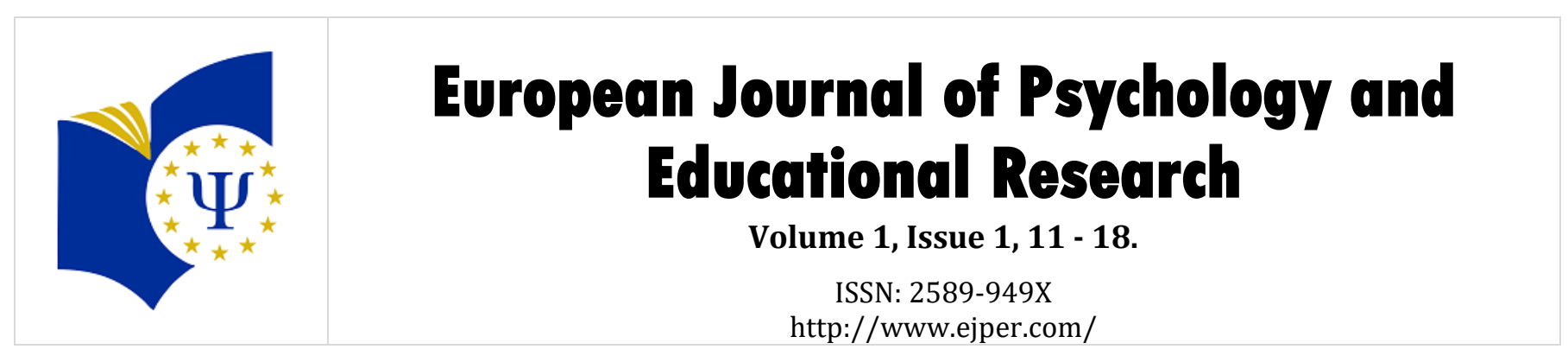

\title{
Social Network Site Usage among Adults: Social Networking Status and Virtual Loneliness
}

\author{
Zihniye Okray* \\ European University of Lefke, \\ CYPRUS
}

\author{
Cemaliye Direktor \\ European University of Lefke, \\ CYPRUS
}

\author{
Anjelika Huseyinzade Simsek \\ Cag University, TURKEY
}

Received: April 04, 2018 Revised: April 28, 2018 Accepted: May 23, 2018

\begin{abstract}
This study examined the relationship between being members of social network sites (SNS) and the reasons for their use among individuals who are between 20-66 years of age. Social networking status and virtual loneliness are examined according to reasons for using SNS of participants. Researcher did a web-based questionnaire upon Facebook (FB) and reached a volunteer group of FB users and gave Social Networking Status Scale ( SNSS) and Virtual Loneliness Scale (VELS) in order to measure participants networking status and virtual loneliness according to socio-demographical variables. SNSS, gender, and age are the strongest predictors of virtual loneliness. Also, male participants, SNSS scores are significantly higher than female participants which indicates that male participants are more dependent on SNS. When time spent online increases individuals get convergence to usual habits in the virtual world. Individuals SNS usage habits effects their normal lives and make them escape to the virtual world.
\end{abstract}

Keywords: Adult, facebook, dependency, social networking, loneliness, status.

To cite this article: Okray, Z., Direktor, C., \& Hüseyinzade Simsek, A. (2018). Social network site usage among adults: Social networking status and virtual loneliness. European Journal of Psychology and Educational Research, 1(1), 11-18. doi: 10.12973/ejper.1.1.11

\section{Introduction}

According to We Are Social and Hootsuite 2017 global digital report; half of the population of the world uses the internet and over 3,75 billion people are online. According to same report one-third of the world, population uses social media and two-thirds of the world's population have smartphones. $37 \%$ of total population of the world are active social network users and 34\% of them are active mobile social network users. Global growth of social media users increases by about 21\% globally every year. Facebook, FB Messenger, and WhatsApp are key global social platforms which have over 1 billion of active users monthly (We are Social \& Hootsuite Global Digital Report, 2017). In the light of these statistical indicators almost half of the world's population dependent or addictive to social media networks.

\section{Media System Dependency Theory}

Media system dependency theory (MSDT) deals with the interactions between media, individual and social institutions. The interactions between individuals and media inspected in micro and the interaction between media and social institutions at macro level (Riffe, Lacy \& Varouhakis, 2008). According to MSDT individuals are goal-oriented and active in seeking appropriate internet platforms and media contents fit them. With this basic assumption, MSDT suggests three dependency areas: The first dependency area is understanding dependency wich includes self-understanding dependency and social-understanding dependency. Self-understanding dependency includes the usage of media resources in order to express individuals own beliefs, behavior and self-image.

Social-understanding dependency refers to individuals who use media resources for understanding events, cultures and people around them. The second dependency is orientation dependency. Orientation dependency divided into two sub categories which are action orientation dependency and interaction orientation dependency. Action orientation

\footnotetext{
* Corresponding author:

Zihniye Okray, European University of Lefke, Psychology Department, North Cyprus

$\bowtie$ zokray@eul.edu.tr
} 
dependency can be described as a guide to the individual's own specific behaviors and concerns the making behavioral decision, interaction orientation dependency, on the other hand, refers to obtain guidance from the media resources on how to behave in personal, professional or in social relationships.

The third dependency area is the play dependency which includes solitary play dependency relations are developed for personal stimulation, aesthetic pleasure and the second content area of play dependency area is social play dependency that stands for the use of media in order attain goals related social recreation (Riffe, Lacy \& Varouhakis, 2008, Huang, Chen \& Kua, 2017).

\section{Research Among Adolescents}

There was a large amount of research done focusing on high school and university students about the usage of social network sites (SNS) especially Facebook (FB). Karaköse, Yırcl, Uygun and Özdemir(2016) study FB addiction and loneliness in high school students and found out that FB usage is not related to loneliness. Mingle \& Adams (2015) studied social network participation and academic performance in high school students and found out that heavy participation of social network sites decreases academic performance meanwhile Ainin, Naqshbandi, Moghavvemi \& Jaafar (2015) reached opposite results as FB usage increases academic performance. Kabre \& Brown (2011)'s study did not predict any influence upon academic performance or quality of life between FB usage. Abdulahi, Samadi \& Gharleghi (2014) studied negative effects of social networking sites especially FB and found out that highly engagement decreases academic performance and increases the health and privacy and security threats of university students. Balcl \& Tiryaki (2014) also studied FB addiction and found out that female students are more prone to be addictive to FB than male students.

\section{Research Among Adults}

We can expand the literature about high school, college, and university students but there is a limited amount of researches done with adults about the usage of social network sites (SNS) especially Facebook (FB). Huang, Chen \& Kua (2017) studied individuals' social network site usage. They make a conclusion like individuals' understanding, orientation and play dependency can be a facilitator besides simultaneous consideration of satisfaction and social presence. The safety and privacy issues about the posts can be an inhibitor of social networking sites usage among individuals over 20 years old.

Adams, Stubbs, and Woods (2005) studied internet use among older adults and found out that if older adults have a positive perception about the usefulness of internet or e-mail they use the internet more often. Another finding of the study was when older adults use the internet more often their perception of ease in use increases while the perception of the complexity of navigation decreases. Brandtzæg, Lüders \& Skjetne (2010) found differences between younger individuals and older adults usage skills. Younger users have more skilled in their FB usage, while older adults have difficulties with navigation and privacy settings. Older adults profiles have completely public profiles without realizing it. In another study done by Steijn (2014) concluded outcomes as adolescents add contacts even they do not know and their contact number is too high, young adults disclosed to much information about themselves and their privacy settings are more vivid than adolescents and adults.

Thackeray, Crookston \& West (2013) studied correlates of health-related social media use among adults and found out that most female participants and younger individuals use social networking site to seek help for their chronic diseases.

Sinclair and Grieve (2017) conducted a research on older adults and found out that older adults gained feelings of FB derived connection similar to levels reported in younger samples. Hutto \& Bell (2014) found out a similar outcome upon older adults that directed communications is significantly correlated with feelings of social satisfaction. Chang, Choi, Bazarova \& Löckenhoff (2015) compared younger adults FB friends with older adults FB friend and found out that older adults friend network ease smaller but contains friends who considered as actual friends. An additionally higher proportion of actual FB friends network related with lower levels of social isolation and loneliness across the lifespan. Özimek \& Bierhoff (2016) investigate FB use intensity according to evolutionary theory and found out that age is inversely related to FB activity. The older individuals used FB less in social comparison. According to Nadkarni \& Hofmann (2012), there are two motivational aspects of FB usage. The first one is the need to belong and the second one is the need for self-presentation.

\section{Purpose of The Current Study}

With this theoretical knowledge, the presenting study's aim is to investigate the reasons of social networking site usage with individuals who are between 20-66 years of age with different educational level and gender in order to evaluate the habits of SNS use.

We hypothesized that age is inversely related to SNS use. Our next hypothesis is that women use SNS sites more than men and our last hypothesis was time spent online was positively related to social networking status and virtual loneliness. 


\section{Method}

\section{Participants}

The questionnaire was formed in Google Forms and the link was sent to only individuals who use Facebook. The data was collected via Facebook from interested individuals between 1-30 of June 2017. Total 110 questionnaires were collected, 3 of them eliminated because of unfilled items. 107 fully completed questionnaires were included in the

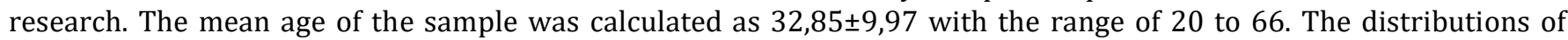
socio-demographical variables of the sample were shown in Table 1. Table 2 shows the aims of participants of using the internet, having which social account or a smartphone.

Table 1. Distribution of sociodemographic variables $(N=107)$

\begin{tabular}{lcc}
\hline Variable & $\mathbf{N}$ & $\mathbf{\%}$ \\
\hline Gender & 73 & 68,2 \\
Female & 34 & 31,8 \\
Male & & \\
Education Level & 6 & 5,6 \\
High School & 5 & 4,7 \\
Two-Year Degree & 62 & 57,9 \\
University Graduate & 34 & 31,8 \\
Masters Degree & & \\
Daily Internet Use & 7 & 6,5 \\
Less than 1 hour & 58 & 54,2 \\
Between 1-3 hours & 35 & 32,7 \\
Between 4-6 hours & 7 & 6,5 \\
7 hours and more & & \\
\hline
\end{tabular}

Table 2. Distribution of Participants according to aims of using the internet and having accounts/smartphones (N=107)

\begin{tabular}{lcccccc}
\hline Aims of Using the Internet & & $\mathrm{N}$ & $\%$ & & $\mathrm{~N}$ & $\%$ \\
\hline Connecting to social network sites & Yes & 89 & 83,2 & No & 18 & 16,8 \\
Watching Movies & Yes & 78 & 72,9 & No & 29 & 27,1 \\
Playing Game & Yes & 35 & 32,7 & No & 72 & 67,3 \\
Research & Yes & 103 & 96,3 & No & 4 & 3,7 \\
Doing Home-work & Yes & 78 & 72,9 & No & 29 & 27,1 \\
Shopping & Yes & 58 & 54,2 & No & 49 & 45,8 \\
e-banking & Yes & 73 & 68,2 & No & 34 & 31,8 \\
Social Network Account & Yes & & & & & - \\
Facebook & Yes & 100 & 100 & No & - & - \\
Tweeter & Yes & 54 & 50,5 & No & 53 & 49,5 \\
Having Smart Phone & Yes & 105 & 98,1 & No & 2 & 1,9 \\
\hline
\end{tabular}

\section{Measures}

Socio-Demographic Information Form: Demographic information form was used by researchers in order to get information from the participants about their age, educational level, gender, time spent connected to the internet the aims of using the internet, having social accounts and having a smartphone.

Social Networking Status Scale ( SNSS): SNSS was developed by Arslan and Kirik (2013) in order to measure the aims of usage of social networking and status. Each item is answered on a 1-5 scale. 1 indicates totally disagree and 5 indicates totally agree. All items are phrased in a positive direction. The scale measures the social networking status under three dimensions which are the addiction, ethic, and convergence. Internal consistency of the scale was found as 0,933 (Arslan \& Kirik, 2013).

Virtual Environment Loneliness Scale (VELS): VELS was developed by Korkmaz, Usta \& Kurt (2014) in order to asses loneliness levels of individuals in virtual environments. Internal consistency scores were calculated as 0.816 for the total VELS, 0.842 for Virtual Socialization, 0.809 for Virtual Sharing, and 0.614 for Virtual Loneliness. Each item is answered on a 1-5 scale. 1 indicates strongly disagree and 5 indicates strongly agree. Items 6, 7, 16, 17, 18, 19 and 20 were reverse coded. From the scale either a total score can be calculated in order to measure virtual loneliness or 3 different scores can be calculated to measure virtual socialization, virtual sharing and virtual loneliness (Korkmaz, Usta \& Kurt, 2014). 


\section{Results}

In order to investigate the differences between categorical variables t-test was used, one-way ANOVA is used to determine whether there are any statistically significant differences between independent groups and linear regression is used to predict the value of a dependent variable over independent variables. Pearson cross-product moment correlation was calculated in order to find the relationship between age and SNSS and VELS scores. The results are as follows.

Table 3. Differences of SNSS and VELS according to gender

\begin{tabular}{|c|c|c|c|c|c|c|}
\hline & \multicolumn{4}{|c|}{ Female $(n=73)$} & \multirow[b]{2}{*}{$t$} & \multirow[b]{2}{*}{$\mathrm{p}$} \\
\hline & $\mathrm{M}$ & SD & $\mathrm{M}$ & SD & & \\
\hline Dependency & 68.05 & 18.36 & 76.32 & 14.76 & 2.30 & $0.023^{*}$ \\
\hline Ethic & 10.42 & 2.23 & 11.88 & 5.74 & 1.89 & 0.062 \\
\hline Convergence & 10.58 & 3.99 & 12.97 & 3.86 & 2.89 & $0.005^{*}$ \\
\hline SNSS & 89.06 & 20.61 & 101.17 & 20.38 & 2.84 & $0.005^{*}$ \\
\hline Virtual Socialization & 21.52 & 4.90 & 26.20 & 4.37 & 4.75 & $0.000^{*}$ \\
\hline Virtual Sharing & 10.69 & 4.29 & 13.44 & 5.79 & 2.74 & $0.007^{*}$ \\
\hline Loneliness & 17.04 & 4.00 & 18.02 & 3.69 & 1.26 & 0.227 \\
\hline VELS & 49.26 & 9.14 & 57.67 & 9.15 & 4.43 & $0.000^{*}$ \\
\hline
\end{tabular}

$* \mathrm{p}<0.05$

T-Test was calcutated in order to see if there is a difference between SNSS and VELS scores according to gender variable. Men $(M=76.32, S D=14.76)$ reported significantly higher levels of dependency in SNSS than women (M=68.05, $\mathrm{SD}=18.36), \mathrm{t}(105)=2.30, \mathrm{p}=0.023, \mathrm{p}<0.05$. Also convergence scores of SNSS differed significantly. Men reported significantly higher scores $(M=12.97, S D=3.86)$ than women $(M=10.58, S D=3.99), t(105)=2.89, p=0.005, p<0.05$. Also men reported higher scores on SNSS total score $(M=101.17, S D=20.38)$ than women $(M=89.06, S D=20.61), t(105)=2.84$, $\mathrm{p}=0.005, \mathrm{p}<0.05$. Virtual socalization and virtual sharing sub-scales scores and also total VELS score differed significantly. Again men reported higher scores on socialization $(M=26.20, S D=4.37)$, virtual sharing (M=13.44, $\mathrm{SD}=5.79)$ and total VELS scores $(\mathrm{M}=57.67, \mathrm{SD}=9.15)$ than women $(\mathrm{M}=21.52, \mathrm{SD}=4.90), \mathrm{t}(105)=4.76, \mathrm{p}=0.000, \mathrm{p}<0.05$, $(\mathrm{M}=10.69, \mathrm{SD}=4.29), \mathrm{t}(105)=2.74, \mathrm{p}=0.007, \mathrm{p}<0.05$ and $(\mathrm{M}=49.26, \mathrm{SD}=9.14), \mathrm{t}(105)=4.43, \mathrm{p}=0.000, \mathrm{p}<0.05$ respectively.

Participants who claimed that they use smartphones and internet for getting access to social network sites reported significantly higher levels of dependency $(M=73.65, S D=15.92)$ than not using with this aim $(M=56.00, S D=18.92)$, $\mathrm{t}(105)=4.153, \mathrm{p}=0.000, \mathrm{p}<0.05$. SNSS total scores differed significantly. Participants who used smartphones and internet for getting access to social network sites reported significantly higher levels of SNSS (M=96.25, SD=19.65) than not using with this $\operatorname{aim}(M=76.39, S D=21.43), t(105)=3.853, p=0.000, p<0.05$. Also they have significantly higher scores on virtual socialization $(M=23.59, S D=4.89)$ then others $(M=20.38, S D=6.02), t(105)=2.39, p=0.018, p<0.05$.

Participants who claimed that they use smartphones and internet for watching movies reported significantly higher scores on convergence $(M=11.84, S D=4.23)$ than not using with this aim $(M=10.00, S D=3.41), t(105)=2.107, p=0.038$, $\mathrm{p}<0.05$. Participants who claimed that they use smartphones and internet for watching movies reported significantly higher scores on total SNSS $(M=95.76, S D=21.27)$ than not using with this aim $(M=85.24, S D=19.37), t(105)=2.329$, $\mathrm{p}=0.022, \mathrm{p}<0.05$.

Another significantly higher scores were found on convergence scores who use smartphones and internet for e-banking $(M=13.068, S D=3.50)$ than not with this aim $(M=7.64, S D=2.50), t(105)=8.088, p=0.000, p<0.05$. Also, individuals who have smartphone significantly reported higher levels of convergence $(M=11.47, S D=4.01)$ than who do not have a smartphone $(M=4.50, S D=0.70) t(105)=, p=0.016, p<0.05$.

Individuals who use smartphones and internet for gaming reported significantly higher levels of ethic scores (M=12.60, $\mathrm{SD}=5.35)$ that not using for gaming $(\mathrm{M}=10.05, \mathrm{SD}=2.82), \mathrm{t}(105)=3.449, \mathrm{p}=0.001, \mathrm{p}<0.05$.

Participants who use internet and smart phones for shopping reported significantly higher levels of dependency (M= 73.98, $\mathrm{SD}=16.75)$, covergence $(\mathrm{M}=14.20, \quad \mathrm{SD}=2.85)$, total SNSS scores $(\mathrm{M}=99.39, \quad \mathrm{SD}=19.98)$, virtual socialization( $M=24.12, S D=5.28)$ and virtual sharing $(M=12.55, S D=5.38)$ and on total score on VELS (M=53.93, $\mathrm{SD}=10.65)$ than not for shopping on dependency $(M=66.77, \mathrm{SD}=18.69), t(105)=2.1038, \mathrm{p}=0.035$, $\mathrm{p}<0.05$, for covergence $(\mathrm{M}=7.95, \mathrm{SD}=2.38), \mathrm{t}(105)=12.133, \mathrm{p}=0.000, \mathrm{p}<0.05$, for total SNSS score $(\mathrm{M}=85.24, \mathrm{SD}=20.22), \mathrm{t}(105)=3.630, \mathrm{p}=0.000$, $\mathrm{p}<0.05$, for virtual socialization $(\mathrm{M}=21.69, \mathrm{SD}=4.4), \mathrm{t}(105)=2.459, \mathrm{p}=0.016, \mathrm{p}<0.05$, for virtual socialization $(\mathrm{M}=10.40$, $\mathrm{SD}=4.17), \mathrm{t}(105)=2.27, \mathrm{p}=0.025, \mathrm{p}<0.05$ an total VELS score $(\mathrm{M}=49.57, \mathrm{SD}=8.48), \mathrm{t}(105)=2.31, \mathrm{p}=0.023, \mathrm{p}<0.05$ respectively.

All of the participats have a FB account and almost half of the participants have a Twitter account. Statistically significant differences were calculated according to having a Twitter account or not on SNSS and VELS scales. Individuals who have Twitter accounts reported significantly higher levels of dependency $(M=76.48, S D=14.46)$, 
covergence $(M=12.42, S D=4.04)$, total SNSS score $(M=99.93, S D=16.91)$ and virtual socialization $(M=24.94, S D=4.82)$, levels than other who do not have Twitter account respectively on dependency $(M=64.77, S D=18.76), t(105)=3.618$, $\mathrm{p}=0.000, \mathrm{p}<0.05$, coverengence $(\mathrm{M}=10.24, \mathrm{SD}=3.88), \mathrm{t}(105)=2.1846, \mathrm{p}=0.005, \mathrm{p}<0.05$, for total SNSS score (M=85.77, $\mathrm{SD}=22.86) \mathrm{t}(105)=3.644, \mathrm{p}=0.000, \mathrm{p}<0.05$ and for virtual socialization $(\mathrm{M}=21.037, \mathrm{SD}=4.86), \mathrm{t}(105)=4.170, \mathrm{p}=0.000$, $\mathrm{p}<0.05$. One-Way ANOVA was calculated in order to find any significant differences according to educational level and time spent online on SNSS and VELS scales.

Table 4. Differences between daily internet use and SNSS scores

\begin{tabular}{|c|c|c|c|c|c|c|c|}
\hline & & SS & & $\mathrm{df}$ & MS & $\mathrm{F}$ & $\mathrm{p}$ \\
\hline \multirow{4}{*}{ Dependency } & Less than 1 & & & & & \multirow{4}{*}{9,695} & \multirow{4}{*}{$0.000^{*}$} \\
\hline & hour & Between groups & 7282,166 & 3 & 2427,389 & & \\
\hline & 1-3 hours & & & & & & \\
\hline & $\begin{array}{c}\text { 4-6 hours } \\
\text { More than } 7\end{array}$ & Within groups & 25789,031 & 103 & 250,379 & & \\
\hline \multirow{4}{*}{ Ethic } & Less than 1 & & & & & \multirow{4}{*}{4,218} & \multirow{4}{*}{$0.007^{*}$} \\
\hline & hours & Between groups & 163,980 & 3 & 54,660 & & \\
\hline & 1-3 hours & & & & & & \\
\hline & $\begin{array}{c}\text { 4-6 hours } \\
\text { More than } 7\end{array}$ & Within groups & 1334,674 & 103 & 12,958 & & \\
\hline \multirow{3}{*}{ Convergence } & $\begin{array}{c}\text { Less than } 1 \\
\text { hour }\end{array}$ & Between groups & 176,180 & 3 & 58,727 & \multirow{3}{*}{3,780} & \multirow{3}{*}{$0.013^{*}$} \\
\hline & 1-3 hours & & & & & & \\
\hline & $\begin{array}{c}\text { 4-6 hours } \\
\text { More than } 7\end{array}$ & Within groups & 1600,026 & 103 & 15,534 & & \\
\hline \multirow{4}{*}{ SNSS } & Less than 1 & & & & & \multirow{4}{*}{11,369} & \multirow{4}{*}{$0.000^{*}$} \\
\hline & hour & Between groups & 11868,986 & 3 & 3956,329 & & \\
\hline & 1-3 hours & & & & & & \\
\hline & $\begin{array}{c}\text { 4-6 hours } \\
\text { More than } 7\end{array}$ & Within groups & 35843,257 & 103 & 347,993 & & \\
\hline
\end{tabular}

$* \mathrm{p}<0.05$

Table 5. Differences between daily internet use and VELS scores

\begin{tabular}{|c|c|c|c|c|c|c|c|}
\hline & & & SS & $\mathrm{df}$ & MS & $\mathrm{F}$ & $\mathrm{p}$ \\
\hline \multirow{2}{*}{$\begin{array}{c}\text { Virtual } \\
\text { Socializatiın }\end{array}$} & $\begin{array}{c}\text { Less than } 1 \text { hours } \\
1-3 \text { hours }\end{array}$ & $\begin{array}{l}\text { Between } \\
\text { groups }\end{array}$ & 229,145 & 3 & 76,382 & \multirow{2}{*}{2,976} & \multirow{2}{*}{$0.035^{*}$} \\
\hline & $\begin{array}{c}\text { 4-6 hours } \\
\text { More than } 7\end{array}$ & $\begin{array}{l}\text { Within } \\
\text { groups }\end{array}$ & 2643,846 & 103 & 25,668 & & \\
\hline \multirow{2}{*}{$\begin{array}{l}\text { Virtual } \\
\text { Sharing }\end{array}$} & $\begin{array}{c}\text { Less than } 1 \text { hours } \\
1-3 \text { hours }\end{array}$ & $\begin{array}{l}\text { Between } \\
\text { groups }\end{array}$ & 67,265 & 3 & 22,422 & \multirow{2}{*}{0,909} & \multirow{2}{*}{0.440} \\
\hline & $\begin{array}{c}4-6 \text { hours } \\
\text { More than } 7\end{array}$ & $\begin{array}{l}\text { Within } \\
\text { groups }\end{array}$ & 2540,960 & 103 & 24,670 & & \\
\hline \multirow{2}{*}{ Loneliness } & $\begin{array}{c}\text { Less than } 1 \text { hours } \\
1-3 \text { hours }\end{array}$ & $\begin{array}{l}\text { Between } \\
\text { groups }\end{array}$ & 11,318 & 3 & 3,773 & \multirow{2}{*}{0,240} & \multirow{2}{*}{0.868} \\
\hline & $\begin{array}{c}\text { 4-6 hours } \\
\text { More than } 7\end{array}$ & $\begin{array}{l}\text { Within } \\
\text { groups }\end{array}$ & 1619,186 & 103 & 15,720 & & \\
\hline \multirow{2}{*}{ VELS } & $\begin{array}{c}\text { Less than } 1 \text { hours } \\
1-3 \text { hours }\end{array}$ & $\begin{array}{l}\text { Between } \\
\text { groups }\end{array}$ & 529,869 & 3 & 176,623 & \multirow{2}{*}{1,838} & \multirow{2}{*}{0.145} \\
\hline & $\begin{array}{l}\text { 4-6 hours } \\
\text { More than } 7\end{array}$ & $\begin{array}{l}\text { Within } \\
\text { groups }\end{array}$ & 9898,673 & 103 & 96,104 & & \\
\hline
\end{tabular}

${ }^{*} \mathrm{p}<0.05$

Educational level was not significant for SNSS. Only VELS virtual socialization sub-scales were significant according to educational level. Analysis of variance showed that the effect of educational level was significant on virtual socialization between two-year degree and masters degree graduates. The main effect of educational level was found for virtual socialization $F(3,103)=3.25, p=0.02$. Post Hoc Test comparison with Tukey showed that two-year degree graduates $(M=9.20, S D=4.54)$ reported significantly less virtual socialization scores than master-degree graduates $(M=11.26$, $\mathrm{SD}=4.04$ ). 
Time spent online was significant for SNSS and VELS virtual socialization subscale. Analysis of variance showed that participants who spent more time on-line reported significantly more dependency $F(3,103)=9.69$, $p=0.000$, more ethic $\mathrm{F}(3,103)=4.21, \mathrm{p}=0.007$ and more $\mathrm{F}(3,103)=4.21, \mathrm{p}=0.013$ convergence. Post Hoc Test comparison with Tukey showed that participants who use internet for less than an hour daily $(M=61.28, S D=20.78)$ reported significantly fewer dependency scores than who uses internet for 4-6 hours daily $(M=80.31, S D=16.76)$ and more than 7 hours $(M=83.57$, $\mathrm{SD}=14.92)$. Post hoc test comparison with Tukey showed participants who used internet for $1-3$ hours daily (M=10.03, $\mathrm{SD}=1.55)$ reported significantly fewer ethics than participants who use internet for 4-6 hours daily $(M=12.05, S D=5.67)$. Similarly, post hoc test comparison with Tukey showed that participants who use internet for 1-3 hours daily $(M=10.51, S D=3.96)$ reported less convergence than participants who use internet for 4-6 hours daily (M=13.17, $\mathrm{SD}=4.04)$. SNSS total score significantly differed $\mathrm{F}(3,103)=11.369, \mathrm{p}=0.000$. Individuals who use internet for one hour or less in daily basis reported less SNSS total scores $(M=80.42, S D=21.12)$ than who uses internet for $1-3$ hours $(M=85.00, S D=16.83), 4-6$ hours $(M=105.21, S D=21.08)$ and 7 hours and more $(M=107.85, S D=17.29)$. The only subscale that significant difference was found is VELS virtual socialization sub-scale $F(3,103)=2.976$, $p=0.035$. Post hoc test comparison with Tukey showed that participants who use internet for $1-3$ hours daily $(M=21.70, S D=5.13)$ reported less virtual socialization than participants who use internet for 4-6 hours daily $(M=24.68, S D=4.95)$. Age was significantly correlated with virtual loneliness $r=0.503, p=0.000, p<0.01$. Social networking status were negatively correlated with age $\mathrm{r}=-0.262, \mathrm{p}=0.006, \mathrm{p}<0.01$.

Table 6. Multiple Linear Regression of Virtual Loneliness Predictors

\begin{tabular}{llllllll}
\hline Variable & $\mathrm{B}$ & $\mathrm{SD}$ & $\beta$ & $\mathrm{t}$ & $\mathrm{p}$ & Partial & Part \\
\hline Constant & 14.347 & 4.842 & - & 2.963 & 0.004 & - & - \\
SNSS & 0.258 & 1.673 & 0.552 & 6.776 & 0.000 & 0.557 & 0.555 \\
Gender & 4.919 & 0.078 & 0.232 & 2.940 & 0.004 & 0.397 & 0.278 \\
Age & 0.217 & 0.092 & 0.218 & 2.763 & 0.007 & 0.092 & 0.263 \\
\hline $\mathrm{R}=0.648$ & $\mathrm{R}=0.420$ & & & & \\
$\mathrm{~F}(3,103)=28.843$ & $\mathrm{p}=0.000$ & & & & & \\
\hline
\end{tabular}

Multiple linear regression analysis was used to test if virtual loneliness significantly predicted participants' sociodemographical variables and social networking status. The results of the regression indicated that three predictors explained $42.0 \%$ of the variance $\left(R^{2}=0.420, F(3,103)=28.843, p=0.000, p<0.05\right)$. It was found that $S N S S(\beta=0.552$, $p=0.000, p<0.05)$, gender $(\beta=0.232, p=0.004, p<0.05)$ and age $(\beta=0.218, p=0.007, p<0.05)$ significantly predicted virtual loneliness.

\section{Discussion}

The aim of the study is to explore the habits and reasons of younger adults and adults SNS usage. In our research nearly all of the participants using the internet to connect SNS $(83,2 \%, n=89)$. All of them have an FB account and half of them also have a Tweeter account. 98,1\% of participants have a smartphone. In our first hypothesis, we assumed that age is inversely correlated with SNS usage. The results of the statistical analysis showed that SNSS is negatively correlated with age which means younger participant uses social network sites more than older participants. The total score of SNSS is higher in younger participants. In literature, there were a vast amount of studies done with younger participants which showed the same results that younger individuals were more dependent on social network sites. Chao Lin et al. (2012: p.198) indicates that young people under 22 have more FB and other SNS dependency than older adults. On the other hand, according to Pew Research Center 2016, Social Media Update Report younger individuals are still using social networking sites more frequently than older individuals but the older individuals SNS using rates increasing instantly too (Pew Research Center, 2016). Another finding with age variable was older participants virtual loneliness scores positively correlated which can be described as older individuals feel more virtual loneliness in social networking sites. Similar findings found by Balcı \& Gölcü (2013: p.274) the more time spent on-line cause individuals to feel more lonely. Burke, Marlow \& Lento (2010: p.1911) found out that friend count and direct communication is associated with increased loneliness.

Time spent online is another variable that is consistent with the literature. In our research, we found out that more time spent on-line causes more dependency, ethical diversities, and more convergence. Also, individuals who use SNS more than an hour daily have a virtual socialization which is not in real life (Balcı \& Gölcü, 2013: p.269-270). McKenna and Bargh (1999: p.256) found out that expressed degree of loneliness is a strong predictor of establishing the more on-line relation. Also, Kraut, Patterson et al (1998: p.1028) indicate that the longer periods of using internet or SNS causes more loneliness.

In our research, we found men are more susceptible to SNS dependency and they frequently use SNS to interact with others. Balcı \& Gölcü (2013: p.269-270) and Çam \& İşbulan (2012: p.17-18) found the consistent result about gender differences in their researches too. They found that men are more susceptible to Facebook addiction than women. 
Another finding of this research is that if individuals who use the internet and social networking for gaming, watching movies, e-banking and shopping their convergence levels increases. Di Gennaro \& Dutton (2007: p.600) found out that individuals use internet and SNS for getting information, entertainment, learning, communication, banking and planning upcoming events consistent these research findings.

In this research, loneliness was predicted by social networking status, gender, and age. Blackwell et al (2017: p.70) found that age was a significant predictor of SNS addiction. Hormes, Kearns \& Timko (2014: p.2082-2085) found gender as a significant predictor of FB addiction.

\section{Conclusions}

In our research main findings suggest that SNS use among older adults are due to virtual socialization. Age and gender are strong predictors of virtual loneliness. The strength of this study is to find out the patterns of SNS usage among older individuals.

\section{Disclosure statement:}

This research did not receive any specific grant funding from agencies in the public, commercial or non-profit organization. Authors did not report any conflict of interest.

\section{References}

Abdulahi, A., Samadi, B. \& Gharleghi, B. (2014). A study on the Negative Effects of Social Networking Sites Such as Facebook among Asia Pacific University Scholars in Malaysia. International Journal of Business and Social Science, 5(10), 133-145.

Adams, N., Stubbs, D. \& Woods, V. (2005). Psychological barriers to Internet usage among older adults in the UK. Medical Informatics and the Internet in Medicine, 30(1), 3-17.

Ainin, S., Naqshbandi, M.M., Moghavvemi, S \& Jaafar, N.I. (2015). Facebook usage, socialization and academic performance. Computers \& Education, 83, 64-73.

Arslan, A. \& Kırı, M.A. (2013). Validity and reliability study of the social networking status scale (SNSS). [in Turkish]. Oneri Dergisi, 10(40), p. 223-231.

Balcl, Ş. \& Gölcü, A. (2013). Facebook Addiction among University Students in Turkey: Selçuk University Example. Turkiyat Arastirmalari Dergisi, 34, 255-278.

Balcı, Ş. \& Tiryaki, S. (2014). Facebook Addiction among High School Students in Turkey. 10th International Academic Conference, Vienna, Proceedings, 119-133, 03 June 2014.

Blackwell, S., Leaman, C., Tramposch, R., Osborne, C. \& Liss, M. (2017). Extroversion, neuroticism, attachment style and fear of missing out as predictors of social media use and addiction. Personality and Individual Differences, 116, 6972.

Brandtzæg, P., Lüders, M. \& Skjetne, J.H. (2010). Too Many Facebook 'Friends'? Content Sharing and Sociability Versus the Need for Privacy in Social Network Sites. International Journal of Human-Computer Interaction, 26(11-12), 1006-1030.

Burke, M., Marlow, C. \& Lnto, T. (2010). Social Network Activity and Social Well-Being. CHI'10 Proceedings of the SIGCHI Conference on Human Factors in Computing Systems, 1909-1912.

Chao Lin, J.Y., Hanh Le, A.N. \& Cheng, S.K.J. (2012). Social media usage and work values: The Example of Facebook in Taiwan. Social Behavior and Personality, 40(2), 195-200.

Çam, E. \& İşbulan, O. (2012). A New Addiction for Teacher Candidates: Social Networks. The Turkish Online Journal of Educational Technology, 11(3), 14-19.

Di Gennaro, C. \& Dutton, W.H. (2007). Reconfiguring Friendships: Social relationships and the Internet. Information, Communication \& Society, 10(5), 591-618.

Hormes, J.M., Kearns, B. \& Timko, C.A. (2014). Craving Facebook? Behavioral addiction to online networking and its association with emotion regulation deficits. Addiction, 109(12), 2079-2088.

Huang, H.Y., Chen, P.L. \& Kua, Y.C. (2017). Understanding the facilitators and inhibitors of individuals' social network site usage. Online Information Review, 41(1),85-101.

Hutto, C. \& Bell, C. (2014). Social Media gerontology: Understanding Social Media Usage Among a Uniques and Expanding Community of Users. 47th Hawaii International Conference on System Science, Proceedings, 1755-1764. 
Kabre, F. \& Brown, U.J. (2011). The influence of Facebook usage on the academic performance and the quality of life of college students. Journal of Media and Communication Studies, 3(4), 144-150.

Karaköse, T. Yırcl, R. Uygun, H. \& Özdemir, T.Y. (2016). The relationship between High School Students' Facebook Addiction and Loneliness Status. Eurasia Journal of Mathematics, Science \& Technology Education, 12(9), 24192429.

Korkmaz, Ö., Usta, E. \& Kurt, İ. (2014). A validity and reliability study of the virtual environment loneliness scale (VELS).[in Turkish]. Hacettepe Üniversitesi Eğitim Fakültesi Dergisi [Haccettepe University Journal of Education], 29(2), 144-159.

Kraut, R., Patterson, M., Lundmark, V., Kiesler, S., Mukopadhyay, T. \& Scherlis, W. (1998). Internet paradox: A social technology that reduces social involvement and psychological well-being? American Psychologist, 53, 1017-1031.

McKenna, K.Y.A. \& Bargh, J.A. (1999). Causes and Consequences of Social Interaction on the Internet: A Conceptual Framework. Media Psychology, 1(3), 249-269.

Mingle, J. \& Adams, M. (2015). Social Media Network Participation and Academic Performance In Senior High Schools in Ghana. Library Philosophy and Practice, 1-52.

Nadkarni, A. \& Hofmann, S.G. (2012). Why do people use facebook? Personality and Individual Differences, 52(3), 243249.

Özimek, P. \& Bierhoff, H.W. (2016). Facebook use depending on age: The influence of social comparisons. Computers in Human Behavior, 61, 271-279.

Pew Research center, Social media update 2016, http://www.pewinternet.org/ 2016/11/11/social-media-update2016/, 04/12/2017.

Riffe, D., Lacy, S., \& Varouhakis, M. (2008). Media system dependency theory and using the Internet for in-depth, specialized information. Web Journal of Mass Communication Research, 11(1), 1-14.

Sinclair, T.J. \& Grieve, R. (2017). Facebook as a source of social connectedness in older adults. Computers in Human Behavior, 66, 363-369.

Steijn, W.M. (2014). A developmental perspective regarding the behaviour of adolescents, young adults, and adults on social network sites. Cyberpsychology: Journal of Psychosocial Research on Cyberspace, 8(2), 68-82.

Thackeray, R., Crookston, B.T., \& West, J. H. (2013). Correlates of health-related social media use among adults. Journal of medical Internet research, 15(1), e12.

We are Social \& Hootsuite Global Digital Report (2017). Digital In 2017 Global Overview: A Collection Of Internet, Social Media, And Mobile Data From Around The World. https://wearesocial.com/special-reports/digital-in-2017-globaloverview, 13/09/2017. 